\title{
PERBANDINGAN SEL DARAH MERAH, SEL DARAH PUTIH DAN HEMOGLOBIN KELELAWAR GENUS Rhinolophus DI GUA ALAMI DAN GUA WISATA KABUPATEN GUNUNG KIDUL, YOGYAKARTA
}

\section{THE COMPARISON PROFILE OF Rhinolophus ERYTHROCYTE, LEUKOCYTE, AND HAEMOGLOBINE AT NATURAL AND TRAVEL CAVES IN GUNUNG KIDUL REGENCY, YOGYAKARTA}

\author{
Tri Harjana \\ Jurusan Pendidikan Biologi, FMIPA Universitas Negeri Yogyakarta \\ *email: Tri_Harjana@uny.ac.id
}

Diterima 22 Februari 2017, disetujui 17 Maret 2017

\begin{abstract}
Abstrak
Penelitian ini bertujuan mengetahui perbedaan jumlah eritrosit, leukosit, hemoglobin dan diferensial leukosit kelelawar genus Rhinolophss di gua alami dan wisata Kabupaten Gunung Kidul Yogyakarta. Jenis penelitian yang dilakukan adalah penelitian eksplorasi. Objek penelitian ini adalah kelelawar Rhinolophus jantan atau betina tidak sedang hamil/ laktasi dan berumur dewasa. 10 sampel kelelawar Rhinolophus berasal dari gua alami Cokakan dan 10 sampel berasal dari gua wisata Gelatik Kabupaten Gunung Kidul Yogyakarta. Kelelawar ditangkap dengan menggunakan jaring kabut/ mist net. Darah kelelawar diambil dari bagian lengan bawah sayap bagian atas (vena). Darah yang keluar dimasukkan ke dalam tabung eppendorf dengan penambahan serbuk EDTA. Kelelawar kemudian diberi madu dan dilepas liarkan. Sampel darah dianalisis menggunakan Hematology Analyzer Sysmex KX-21. Data jumlah eritrosit dan leukosit dianalisis dengan analisis statistik Mann- Whitney Test, kadar hemoglobin dianalisis dengan T tes untuk mengetahui ada tidaknya perbedaan signifikan pada perbandingan rerata jumlah eritrosi, leukosit dan kadar hemoglobin dua kelompok data kelelawar yang berasal dari dua gua dengan pola pengelolaan yang berbeda. Rerata jumlah eritrosit, leukosit, hemoglobin dan diferensial leukosit dibuat menjadi diagram batang untuk mengetahui selisih rerata jumlah dua kelompok data. Hasil penelitian menunjukkan bahwa tidak ada perbedaan yang signifikan $(\mathrm{p}>0,05)$ pada perbandingan jumlah eritrosit, leukosit, hemoglobin dan diferensial leukosit di gua alami Cokakan dan wisata Glatik Kabupaten Gunung Kidul Yogyakarta. Terdapat kecenderungan jumlah eritrosit dan hemoglobin cenderung lebih tinggi pada kelelawar di gua Cokakan, sedang leukosit dan diferensial leukosit kelelawar Rhinolophus yang lebih tinggi pada gua wisata Glatik
\end{abstract}

Kata kunci: gua, kelelawar, eritrosit, hemoglobin, leukosit, diferensial leukosit

\begin{abstract}
This research aims to determine differences of eritrocyte, leukocyte, hemoglobin count and differential leukocyte of Rhinolophus in a natural and travel cave at Gunung Kidul, Yogyakarta. This is an exploration research. The object of this study was Rhinolophus adults either male or female.The females are not pregnant or lactating. 10 samples of Rhinolophus derived from Cokakan Cave and 10 samples derived from Glatik Cave in Gunung Kidul, Yogyakarta. Bats captured using mist nets. Blood taken from the bat wing upper forearm (vein). The blood put in eppendorf tubes with the addition of EDTA powder. Then bats given honey and released. Blood samples were analyzed using the Hematology Analyzer Sysmex KX-21. Data were analyzed by Mann-Whitney and t test statistical analysis. This test to determine a significant difference in the comparison of the average of eritrocyte, hemoglobin, leukocytes bat from two caves with different management patterns. The average and differential leukocyte made into a bar chart to determine the difference in the average number of data. The results showed that there was no significant difference ( $p>$ $0.05)$ in the ratio of the leukocyte count and differential leukocyte in Cokakan Cave and Gelatik Cave. There is a tendency of the leukocyte count and differential leukocyte of Rhinolophus is higher in the Glatik Cave. But eritrocyte dan hemoglobin a tendency higher in Cokakan cave
\end{abstract}




\section{Pendahuluan}

Kelelawar di Indonesia berdasarkan makanannya dibagi menjadi dua kelompok besar, yaitu sub ordo Megachiroptera pemakan tumbuhan dan Microchiroptera pemakan serangga [1]. Sebagian besar kelelawar pemakan serangga, termasuk hama tanaman pertanian. Banyak jenis kelelawar yang populasinya merosot akhir- akhir ini, dan bahkan ada jenis- jenis tertentu terancam punah. Hilangnya habitat merupakan faktor yang paling besar berpengaruh terhadap penurunan jumlah populasi kelelawar [2].

Keadaan di atas menggambarkan bahwa terdapat dampak negatif dari pengelolaan gua sebagai lokasi wisata, yaitu berpotensi mengganggu fungsi utama gua sebagai habitat berbagai macam fauna salah satunya kelelawar. Penelitian ini dilakukan untuk mengetahui sejauh mana pengaruh pola pengelolaan gua menjadi lokasi wisata terhadap kondisi kesehatan kelelawar. Tingkat kesehatan kelelawar dilihat berdasarkan kualitas darah yaitu jumlah eritrosit, leukosit, hemoglobin dan diferensial leukosit yang berperan dalam mekanisme kekebalan tubuh.

Populasi kelelawar di Indonesia cenderung menurun, belum ada penelitian yang menunjukkan secara pasti jumlah penurunannya namun beberapa gua menunjukkan adanya kondisi tersebut. Contohnya, Gua Lawa Kabupaten Purbalingga Jawa Tengah dulu banyak kelelawarnya sehingga disebut gua lawa, tetapi sekarang tidak seekor pun kelelawar yang tinggal. Gua Sipit Trenggalek juga demikian, yang dulu dikabarkan penuh kelelawar, sekarang tinggal puluhan ekor saja. Gua Kampret, Bahorok, Sumatra Utara konon juga banyak kelelawarnya sehingga diberi nama Kampret, Suatu studi pada tahun 1998 melaporkan kelelawarnya tinggal sedikit/ kurang dari 200 ekor. Hilangnya kelelawar ini karena gua yang dihuninya dibuka untuk umum sebagai obyek wisata [2].

\section{Metode Penelitian}

Jenis penelitian. Jenis penelitian yang dilakukan adalah penelitian eksploratif. Subali [3] mengatakan bahwa penelitian eksploratif adalah penelitian yang memuat atau menyajikan data berupa fakta yang ada tanpa melakukan treatmen.

Waktu dan tempat penelitian. Pengambilan sampel darah kelelawar dilakukan pada tanggal 2123 Agustus 2016 di gua Cokakan Desa Gading, Kecamatan Playen, Kabupaten Gunungkidul
Yogyakarta dan gua wisata Glatik Desa Bejiharjo, Kecamatan Karangmojo, Kabupaten Gunungkidul Yogyakarta. Analisis sampel darah dilakukan tanggal 22- 28 Agustus 2016 di Laboratorium Penelitian dan Pengujian Terpadu (LPPT) Universitas Gadjah Mada.

Populasi yang diambil pada penelitian ini adalah kelelawar genus Rhinolophus di gua alami Cokakan dan gua wisata Glatik Kabupaten Gunung Kidul Yogyakarta. Sampel kelelawar diambil dengan menggunakan purposive sampling. Subali (2010: 36) mengatakan bahwa purposive sampling adalah pengambilan sampel dengan menggunakan pertimbangan tertentu setelah mengetahui karakteristik populasi. Sampel yang digunakan adalah 10 ekor kelelawar Rhinolophus pada masing- masing gua.

Kelelawar ditangkap dengan menggunakan jaring kabut/ mist net yang dipasang pada mulut gua di gua Glatik dan gua Cokakan Kabupaten Gunung Kidul Yogyakarta. Setelah terperangkap, kelelawar tersebut diambil dengan cara membebaskan tubuh kelelawar dari jeratan jaring dan dimasukkan ke dalam kantong belacu. Pengambilan sampel darah kelelawar diambil dari bagian sayap kelelawar dengan cara mengolesi pembuluh darah pada sayap bagian atas (vena) dengan alkohol $70 \%$ kemudian ditusuk pelan dengan jarum spuit $5 \mathrm{ml}$. Darah yang keluar dihisap menggunakan glass micro- hematocrit capillary tubes sebanyak $\pm 0,2 \mathrm{ml}$ lalu dimasukkan ke tabung eppendorf $1 \mathrm{ml}$ dengan penambahan $\pm 1 \mathrm{mg}$ serbuk EDTA, kemudian diberi label. Kelelawar kemudian diberi madu dan dirilis. Penghitungan jumlah leukosit dan diferensial leukosit dilakukan di LPPT UGM dengan menggunakan Hematology Analyzer Sysmex KX- 21.

Data yang diperoleh merupakan data jumlah eritrosit, leukosit, hemoglobin dan diferensial leukosit kelelawar Rhinolophus di gua alami Cokakan dan gua Glatik Kabupaten Gunung Kidul Yogyakarta. Analisis data menggunakan MannWhitney Test dan $\mathrm{T}$ tes. Analisis ini dilakukan untuk mengetahui perbedaan rerata jumlah eritrosit, leukosit dan kadar hemoglobin Rhinolophus dari dua habitat yang berbeda (alami/ wisata). Data diferensial leukosit dibuat diagram batang untuk mengetahui selisih perbedaan rerata jumlah. Data pendukung penelitian ini adalah berupa data kunjungan pada gua wisata Glatik dan data klimatik gua meliputi suhu, kelembaban, intensitas cahaya dan kecepatan angin. 


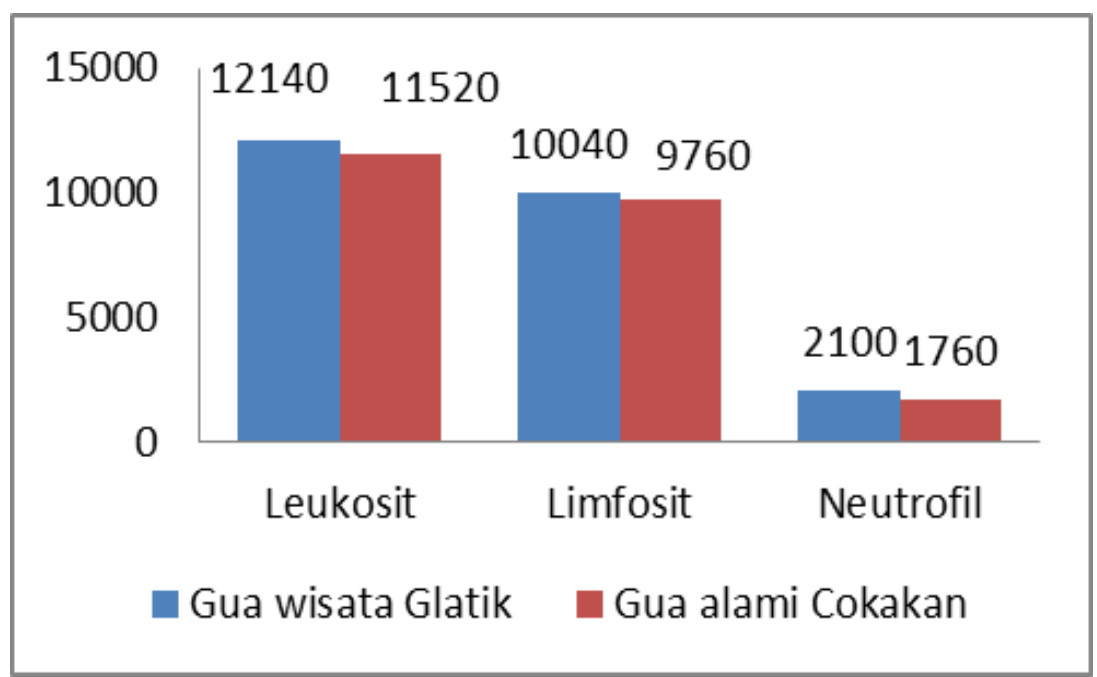

Gambar 1. Diagram perbandingan rerata jumlah leukosit dan diferensial leukosit leukosit kelelawar Rhinolophus affinis di gua alami Cokakan dan gua wisata Glatik

Tabel 1. Hasil Uji Mann-Whitney Test

\begin{tabular}{lrrr}
\hline & \multicolumn{1}{c}{ Leukosit } & \multicolumn{1}{c}{ Limfosit } & \multicolumn{1}{c}{ Neutrofil } \\
\hline Mann- Whitney U & 41.000 & 43.000 & 40.000 \\
Wilcoxon W & 96.000 & 98.000 & 95.000 \\
Z & -.680 & -.529 & -.761 \\
Asymp. Sig. (2- tailed) & .496 & .597 & .446 \\
Exact Sig. [2*(1- tailed Sig.)] & $.529^{\mathrm{b}}$ & $.631^{\mathrm{b}}$ & $.481^{\mathrm{b}}$ \\
\hline
\end{tabular}

Analisis data menggunakan Mann-Whitney Test dan $\mathrm{T}$ tes. Analisis ini dilakukan untuk mengetahui perbedaan rerata jumlah eritrosit, leukosit dan hemoglobin Rhinolophus dari dua habitat yang berbeda (alami/ wisata). Data diferensial leukosit dibuat diagram batang untuk mengetahui selisih perbedaan rerata jumlah.

\section{Hasil dan Pembahasan}

Hasil analisis Mann-Whitney Test pada perbandingan data jumlah leukosit dan diferensial leukosit kelelawar di gua alami dan gua wisata menunjukkan tidak adanya perbedaan yang signifikan $(p>0,05)$. Pada penelitian ini, peneliti tidak dapat memastikan pengaruh proses penangkapan sampai darah diambil terhadap jumlah leukosit.

Variasi komposisi dan jumlah leukosit merupakan bentuk penyesuaian oleh pengaruh adaptasi dengan lingkungan selama menghadapi tekanan hidup di alam. Wimsatt, William A [4] menyatakan bahwa kita dapat mengelompokkan pengalaman hewan yang tertekan dengan melihat data hematologinya, seberapa banyak kelelawar menghadapi gangguan dan infeksi selama hidup di dunia liar atau pada habitat naturalnya dapat dilihat dari hematologinya.

Pada penelitian ini karena terbatasnya sumber yang menjelaskan tentang hematologi kelelawar, acuan pada pembahasan ini adalah hematologi mamalia secara umum. Terdapat sedikitnya dua kemungkinan yang terjadi pada tingginya jumlah leukosit dan diferensial leukosit kelelawar di gua wisata Glatik yaitu akibat dari stres dan akibat dari serangan bakteri, virus atau jamur.

Kemungkinan pertama yang terjadi pada kelelawar Rhinolophus di gua wisata Glatik adalah stres. Borrel [5] mengatakan bahwa stres yang bersifat akut akan merangsang medula adrenal untuk mensekresikan kotekolamin (epinefrin dan norepinefrin) yang akan menyebabkan terjadinya peningkatan presentase neutrofil dan limfosit. Jain [6] mengatakan bahwa stress dapat berupa stress fisik, emosi atau stress yang di induksi oleh penyakit. Perubahan jumlah leukosit total pada keadaan ini diperantarai oleh epinefrin. Pada sekresi epinefrin terjadi leukositosis yang bersifat sementara dan sangat singkat muncul dalam sirkulasi darah. Pelepasan epinefrin ini 
mengakibatkan mobilisasi neutrofil dan limfosit dari pool marginal ke dalam sirkulasi darah, sehingga terjadi neutrofilia dan limfositosis yang bersifat sementara.

Kemungkinan yang kedua adalah terjadi leukositosis pada kelelawar di gua wisata Glatik. Leukositosis merupakan kondisi dimana terjadi peningkatan jumlah leukosit dalam aliran darah. Hal ini dikarenakan lebih banyaknya neutrofil yang dilepas, neutrofil merupakan salah satu bentuk sel fagositik dalam darah yang merespons adanya rangsangan berupa konfigurasi asing bakteri. Dellmann \& Brown [7] menyebutkan bahwa neutrofil merupakan sel utama dalam pertahanan non spesifik tubuh. Neutrofil merespon terhadap infeksi, pada kasus penyakit bakteri lazimnya jumlah neutrofil dalam darah meningkat. Pada saat yang sama, sumsum tulang merah diragsang untuk melepas lebih banyak neutrofil dalam aliran darah sehingga terjadilah leukositosis.

Lebih tingginya rerata leukosit Rhinolophus di gua wisata Glatik merepresentasikan keadaan kelelawar yang lebih banyak mendapat gangguan. Jumlah sel darah merah dan kadar hemoglobin kelelawar di gua alami Cokakan cenderung lebih tinggi bila dibanding di gua wisata Gelatik. Hal ini kemungkinan karena faktor tidak adanya gangguan manusia terhadap kelelawar di gua Cokakan dan masih baiknya vegetasi di sekitar gua Cokakan sebagai tempat kehidupan serangga yang menjadi makanan kelelawar, sehingga memberi gambaran darah yang lebih baik dibanding di gua wisata Gelatik [8,9].

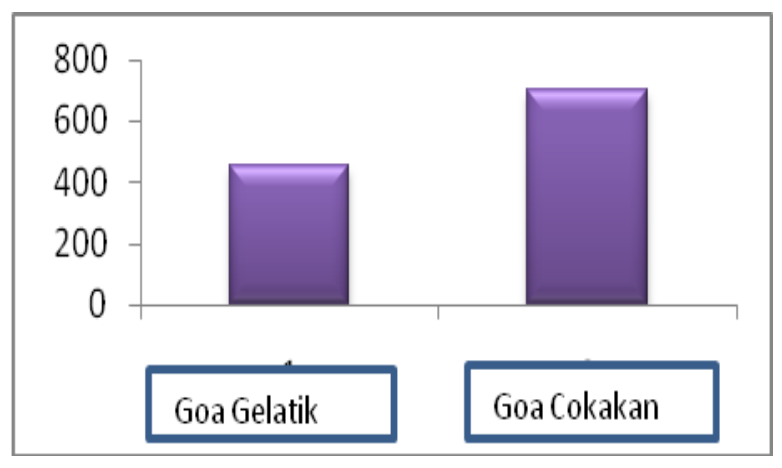

Gambar 2. Perbandingan jumlah eritrosit kelelawar di gua wisata Gelatik dan Gua alami Cokakan

Hasil uji Mann Whitney menunjukkan tidak ada beda yang signifikan $(P>0,5)$ antara jumlah eritrosit kelelawar di gua Cokakan dan gua Gelatik, tetapi di gua Cokakan cenderung lebih tinggi.

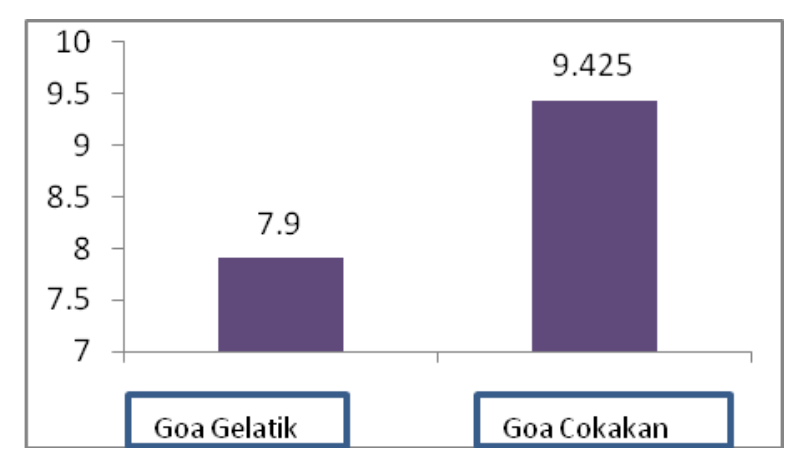

Gambar 3. Perbandingan kadar hemoglobin kelelawar di gua wisata Gelatik dan gua alami Cokakan

Berdasar hasil uji $\mathrm{T}$ tes tidak ada beda yang signifikan (P.>0,05) antara hemoglobin kelelawar di kedua gua, tetapi yang di gua alami Cokakan cenderung lebih tinggi

\section{Simpulan}

Berdasarkan penelitian yang telah dilakukan dapat disimpulkan bahwa tidak ada perbedaan yang signifikan ( $p>0,05)$ pada jumlah eritrosit, leukosit dan hemoglobin di gua alami dan di gua wisata. Jumlah leukosit Rhinolophus di gua wisata cenderung memiliki rerata yang lebih tinggi.jumlah eritrosit dan kadar hemoglobin cenderung lebih tinggi pada kelelawar di gua alami Cokakan. Selain itu, tidak ada perbedaan yang signifikan $(p>0,05)$ pada jumlah diferensial leukosit berupa di gua alami dan di gua wisata. Jumlah diferensial leukosit di gua wisata Gelatik cenderung memiliki rerata yang lebih tinggi.

\section{Ucapan Terima Kasih}

Penelitian ini terlaksana atas dukungan dana DIPA FMIPA UNY tahun 2016. Untu itu Tim Peneliti mengucapkan terima kasih kepada Dekan FMIPA UNY beserta jajarannya atas peluang dan dana yang diberikan.

\section{Pustaka}

[1] Suyanto Agustinus. (2001). Kelelawar di Indonesia. Bogor: LIPI.

[2] Kingston T, Boo LL, Akbar Z. (2006). Bats of Krau Wildlife Reserve. University. Kebangsaan Malaysia: Bangi

[3] Subali Bambang. (2010). Metodologi Penelitian Biologi. Yogyakarta: FMIPA UNY 
[4] Baratawidjaja, Karnen Garna. (2000). Imunologi edisi 5. FKUI: Jakarta

[5] Campbell, N.A., Reece, J.B. Urry, L.A., Wasserman, S.A., Minorsky, P.V., dan Jackson, R.B. (2010). Biologi jilid 3 (edisi 8). Jakarta: Erlangga

[6] Borisseko, A. V. Kruskop, S. V. (2003). Bats of Vietnam and Adjacent Territories an Identification Manual. Joint Rusian-Vietnamse Science and Technological Tropical Zoologycal Museum of Moscow M. V. Lomonosov State University Moscow
[7] Dellman dan Brown. (1989). Buku Teks Veteriner. Edisi ke 3. Penerjemah: Hartono, R. judul buku asli: Textbook of Veterrinary Histology. Universitas Indonesia Press. Jakarta

[8] Tizard Ian. (1988). Pengantar Imunologi Veteriner. Airlangga University Press: Surabaya

[9] Wimsatt, William A.(1977). Biology of Bats Volume III. Academic Press: London 